\title{
The Attitude of Healthcare Professionals Towards Disabled Individuals
}

\author{
Sağlık Çalışanlarının Engelli Bireylere Yönelik Tutumu
}

\author{
Çağlar şiMŞEK ${ }^{\oplus}$, Sabanur ÇAVDAR ${ }^{\oplus}$, Ebru TEMIZ ${ }^{\oplus}$, Burcu GÜNDÜZ ${ }^{\oplus}$, Ebru YILMAZ YALÇINKAYA $\odot$
}

\section{ABSTRACT}

Objective: The research was planned to investigate the attitudes of healthcare professionals in Istanbul towards people with disabilities within the scope of the "Be Happy in Life" project, which is conducted under the coordination of Istanbul Provincial Health Directorate with the aim of increasing the wellbeing of the disabled and their families and professionals who provided healthcare for them.

Method: This study is a descriptive study on healthcare professionals working in health institutions in Istanbul affiliated with the Ministry of Health. The questionnaire developed according to the literature data, and the "Attitude Toward Disabled Persons" (ATDP) scale were used to collect data. This online survey was conducted with 704 voluntarily participating healthcare professionals working in health institutions in Istanbul.

Results: Healthcare professionals participating in the study were mostly women (77.1\%), married $(61.8 \%)$ and the mean age of the study population was $35.97 \pm 8.76$ years. Most $(77.6 \%)$ of them have an undergraduate education or above; and $48.6 \%$ of them were nurses, and midwives, Average duration of employment in the profession was $12.93 \pm 9.19$ years. ATDP scale scores were higher in females than males $(p=0.036)$, and higher in singles than in married $(p=0.033)$. Average ATDP scale scores were significantly higher in participants whose income exceeded their expenses $(p=0.033)$. A significant difference was detected between professional groups regarding average ATDP scale scores $(p<0.001)$. The highest average score was for the "social worker/psychologist/physiotherapist" group, while the lowest scale score was for the "Data Entry Operator/Data Preparation and Control Operator" group. In correlation analyses performed, no significant relationship was found between the age of healthcare profesionals or the duration of their employment in the profession and ATDP scale scores $(r=-0.014 ; p=0.703$ and $r=-0.038$; and $p=0.319$ ).

Conclusion: Courses that increase attitudes and awareness towards disabled people should be included in the education curriculum of health professionals at all levels. The perception of disability as "disorder", "abnormality" or "impaired" should be supported by organizing in-service training programs related to the disabled at regular intervals in health institutions.

Keywords: Healthcare professional, disability, attitude

Öz

Amaç: Araștırma İstanbul il Sağlık Müdürlüğü koordinatörlüğünde yürütülen engelliler ve onlara bakım veren aileleri ile profesyonellerin iyilik halinin artırılması konulu "Be Happy in Life" projesi kapsamında, istanbul'daki sağlık çalışanlarının engelli bireylere yönelik tutumlarının amacıyla planlandı.

Yöntem: Tanımlayıcı tipteki araştırmanın evrenini İstanbul il Sağlık Müdürlüğü'ne bağlı kurumların çalışanları oluşturdu. Veri toplama aracı olarak literatür doğrultusunda geliştirilen anket formu ve "Yetersizlikten Etkilenmiş Kişilere Yönelik Tutum Ölçeği" (YEKYTÖ) kullanıldı. Veri analizi, SPSSv21 istatistik programında tanımlayıcı analizler, bağımsız gruplarda t testi, tek yönlü varyans analizi ve ileri analizler ile yapıldı. Bu online anket çalışması, Istanbul'da kamu sağlık kuruluşlarında çalışan, gönüllü olarak katılan 704 sağlık çalışanı ile yürütülmüşsür.

Bulgular: Araştırmaya katılan sağlık çalışanlarının \%77,1'inin kadın; \%61,8'inin evli; yaş ortalamasının $35,97 \pm 8,76$ yıl; \%77,6'sının eğitim düzeyinin lisans ve üzerinde olduğu; \%48,6'sının hemşire/ebe olduğu

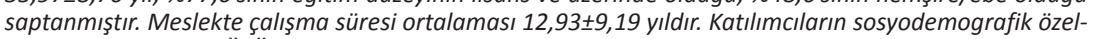
liklerine göre YEKYTÖ Ölçek puan ortalamaları incelendiğinde, kadınların erkeklere göre $(p=0,036)$; bekarlarda evlilere göre $(p=0,033)$ puan ortalamaları anlamlı yüksek bulundu. Gelir durumuna göre geliri giderinden fazla olanların YEKTYÖ puan ortalamaları anlamlı yüksek bulundu $(p=0,003)$. Meslek gruplarına göre YEKYYÖ ölçek puan ortalamalar arasında önemli fark saptandı $(p<0,001)$. En yüksek puan ortalaması olan meslek grubu "sosyal çalışmacı/psikolog/fizyoterapist" grubu iken, en düşük ölçek puanını "VGG/VHKi: Veri Giriş Görevlisi/Veri Hazırlama Kontrol işletmeni" meslek grubu aldığı bulundu. Yapılan korelasyon analizlerinde, sağlık çalışanlarının yaşı veya meslekte çalışma süreleri ile YEKYTÖ puanları arasında anlamlı ilişki saptanmadı ( $r=-0,014 ; p=0,703$ ve $r=-0,038 ; p=0,319)$.

Sonuç: Sağlık çalışanlarının eğitimlerinin her aşamasında müfredatta engellilere yönelik tutum ve farkındalığı artırıcı derslere yer verilmelidir. Sağlık kuruluşlarında engelliler ile ilgili hizmet içi eğitim programları belirli aralıklarla düzenlenerek engelliliğe dair "bozukluk" ya da "anormallik" algısının "farklılı" olarak algılanması desteklenmelidir.

Anahtar kelimeler: Sağlık çalışanı, engellilik, tutum

(C) Telif hakkı SBÜ Gaziosmanpaşa Eğitim ve Araştırma Hastanesi. Logos Tıp Yayıncılık tarafindan yayınlanmaktadır. Bu dergide yayınlanan bütün makaleler Creative Commons 4.0 Uluslararası Lisansı ile lisanslanmıştr.

(c) Copyright Association of Publication of the Gaziosmanpaşa Training and Research Hospital.

This journal published by Logos Medical Publishing.

Licenced by Creative Commons Attribution 4.0 International (CC)

\begin{tabular}{r}
\hline Received/Geliş: 04.11.2020 \\
Accepted/Kabul: 18.11.2020 \\
Published Online: 23.12 .2020
\end{tabular}

Cite as: Şimşek Ç, Çavdar S, Temiz E, Gündüz B, Yılmaz Yalçınkaya $E$. The attitude of healthcare professionals towards disabled individuals. Jaren. 2020;6(3):54553.

Çağlar Şimşek Taksim Eğitim ve Araştırma Hastanesi, İstanbul - Türkiye erkhems@hotmail.com ORCID: 0000-0002-7077-7486

S. Çavdar 0000-0001-5490-6877 Ümraniye ilç̧e Sağlık Müdürlüğü, Istanbul, Türkiye

E. Temiz 0000-0001-5836-9845 Sağlık Bilimleri Üniversitesi Bakırköy Dr. Sadi Konuk Eğitim ve Araştırma Hastanesi, Istanbul, Türkiye

B. Gündüz 0000-0003-2779-6101 Üsküdar Devlet Hastanesi, istanbul, Türkiye

E. Yılmaz Yalçınkaya 0000-0003-0508-8841 Sağlık Bilimleri Üniversitesi Gaziosmanpaşa Eğitim ve Araştirma Hastanesi, Istanbul, Türkiye

"4-6 Aralık 2020 tarihinde 7. Tıbbi Rehabilitasyon Kongresi'nde "Sağlık Calışanlarının Engelli Bireylere Yönelik Tutumu: Be Happy in Life Avrupa Birliği Erasmus + Proje Araştırması" başlığıyla sözel bildiri olarak sunulmuştur. 


\section{INTRODUCTION}

Disability, congenital or acquired is a condition that significantly restricts an individual's life functions for any reason and also affects the physical, mental, psychological and social reasoning ${ }^{(1)}$. It is stated that the first legal arrangements regarding disability were mostly shaped by a medical point of view, and that disability could be considered a public health problem in time, and some arrangements were made to enable disabled individuals to participate in social life easily ${ }^{(2)}$. According to the World Disability Report prepared by the World Health Organization (WHO) in 2011 the incidence rate of disability in adults worldwide was $15.6 \%$ (11.8\% for high-income code, $18.0 \%$ for those with low income) ${ }^{(3)}$.

According to the Social Model, disability is a set of conditions (negative attitudes such as marginalization, exclusion) put forward by the environment to restrict the individual's full participation in society. To compare these two models, the medical model approaches disability from biomedical perspective, while the social model from the point of view of 'integration', and 'inclusion' (4).

Although approximately 8.5 million chronic patients and disabled people living in Turkey with these individuals can not be scheduled because a lot of obstacles and regulations that limit their mobility in the environment are suitable to face many problems in social life. Results of Turkey Disability Survey conducted in 2002 also reveal that a number of important issues about the accessibility of persons with disabilities are prevalent in Turkey ${ }^{(5)}$.

The social model asserts that the situation that makes individuals disabled does not arise from their disability, and criticizes the reasons that restrict these individuals in the society and similar negative mentality and attitudes ${ }^{(6)}$. The medical model explains the disability depending on the individual's inadequacy and pathology ${ }^{(7)}$. In this context, to evaluate individuals with disabilities based solely on the medical model causes emergence of discriminatory, stigmatizing and exclusionary attitudes towards disabled individuals in the society.

It is known that healthcare professionals have an important role in protecting and improving the health of individuals with disabilities and their families. It is important that healthcare personnel have the necessary knowledge, equipment and attitude in order to meet all the needs of disabled individuals and their families professionally ${ }^{(8)}$.

This research was conducted under the coordination of the Istanbul Provincial Health Directorate, within the scope of the ERASMUS + KA2 EU project (Project No: 2018-1-TR01-KA204-058392) titled "Be Happy in Life", which is about increasing the well-being of the disabled and their families and professionals. It was conducted to investigate the attitudes of healthcare professionals in the Metropolitan City of Istanbul towards disabled individuals.

\section{METHOD}

Type of the Study: This study was a descriptive study.

Population and Sample of the Study: The population of the study consisted of approximately a hundred thousand healthcare professionals working in health institutions in Istanbul affiliated with the Ministry of Health. Voluntary response sampling, one of the non-probability sampling methods, was applied. Since the announcement of volunteer participation in research was conducted through official correspondence, the number of healthcare workers, people reached by the survey could not be calculated. The questionnaire was answered by 707 health workers. 3 participants were excluded from the analysis because scale scores could not be calculated since they did not answer all of the items. Ultimately, the research was conducted with 704 healthcare workers who participated voluntarily.

Data Collection Tools: The study was conducted with an online questionnaire that was prepared according to the literature by the researchers ${ }^{(10,11)}$. In the first part of the questionnaire, there were 11 questions including 7 questions investigating the sociodemographic characteristics of the participants (age, gender, marital status, educational status, profession, working time, income status) and 4 questions investigating their experiences regarding disability (the presence of a disabled person in the family or close 
environment, disability-related education etc. event attendance status, working experience in a unit dealing with the disabled, willingness to take part in a training/event related to the disabled). The second part of the questionnaire included the "Attitude Toward Disabled Persons" (ATDP) scale. ATDP scale was developed to evaluate attitudes towards persons with disabilities regardless of the disability group ${ }^{(9)}$. It was adapted into Turkish and its validity and reliability analysis was made by Özyürek ${ }^{(12)}$. The scale consists of 6-point Likert type 20 items (+3 Strongly Agree, +2 Agree, +1 Somewhat Agree, -1 Somewhat Disagree, -2 Disagree, -3 Strongly Disagree). While calculating the scale score, items 2, $5,6,11$ and 12 are scored reversely; then the total score is calculated by adding +60 to the obtained score, eliminating negative values (maximum 120 points). The high scale score indicates that disabled people are perceived similarly to non-disabled people. However, the low scale score indicates that disabled people perceive differently from non-disabled people. It is stated that having a low score from the scale means that people with disabilities are not only perceived differently, but people maintain a biased attitude towards them because they are seen as "inferior" or "unworthy" (13). The validity of the ATDP Scale was evaluated with the Cronbach's alpha coefficient (0.732). Scale validity was considered sufficient because it was larger than 0.70 .

Data Collection: The questionnaire of the study was transferred to Google Forms and the data collection process was carried out online. An official participation invitation letter has been written by the Istanbul Provincial Health Directorate R\&D and Projects Unit to public healthcare institutions in Istanbul. Health institutions have noticed this letter to the healthcare personnel working within their organization using in-house announcement channels (Hospital Management Information System-"HYBS", Electronic Document Management System-“EBYS”, mail groups, Whatsapp groups, in-house SMS, written announcements, etc.). Healthcare workers who volunteered to participate in the study answered the questionnaire items.

Control and Organization of Dataset: Since the data were collected electronically, it was accepted that there were no data entry errors. When the data were checked before the analysis, it was found that 3 participants did not answer all of the scale items. These participants were excluded from the study. Before the analysis, the professions were grouped. Seven groups were formed: 1) Physician 2) Nurse/Midwife 3) Social worker/Psychologist/Physiotherapist 4) Health technician 5) Data Entry Operator/Data Preparation and Control Operator (DEO/DPCO) 6) Other healthcare professionals=Other health licensees (excluding healthcare managers): comprised Paramedics, Dieticians, Child development specialists, Dental clinic support staff, Biologists, Pharmacists, Dental prosthesis technicians, Environmental health technicians, Chemists, Laboratory staff 7) Staff providing support and management services: IT, Office staff, Computer operator, Officer, Accounting, Architect, Engineer, Administrative staff, Worker, Technical staff, Cleaning staff, and Security officer.

Evaluation of Data: The SPSS v21 package program was used for data analysis and statistical evaluation. Data were summarized by means, standard deviations, minimum and maximum variables, medians and percentages. Independent groups t-test and ANOVA test were used for the comparison among groups. Post-hoc analysis of significant differences in the outputs of the ANOVA test was assessed by the Bonferroni test. Pearson and Spearman Correlation Analysis examined the associations between different variables. Statistical significance level was accepted as $\mathrm{p}<0.05$.

Ethical Dimension of the Study: The study was approved by the Ethical Committee of Health Sciences University Gaziosmanpaşa Taksim Training and Research Hospital (2019/163). The purpose of the research was explained to the participants who accepted to participate in the study. It was informed that participation in the study was in line with the voluntary principle.

Limitations of the Study: University hospital and private hospital employees in Istanbul were not included in the sample.

\section{RESULTS}

The sociodemographic characteristics of the 704 healthcare workers participating in the study are 
presented in Table 1. Most $(77.1 \%)$ of the participants were women, and $61.8 \%$ were married and the mean age of the study population was $35.97 \pm 8.76$ (median 35 ) years. Most (77.6\%) of them have an undergraduate education and above, and $48.6 \%$ of them were nurses/midwives. The average duration of employment in the profession was $12.93 \pm 9.19$ (median 11) years.

When the experiences of the healthcare professionals participating in the study on disability were evaluated, it was found that $49.6 \%$ of them were disabled individuals in their family or close environment and $24.1 \%$ of them had experience of working in a unit related to disabled people. It was found that

Table 1. Sociodemographic Characteristics of the Healthcare Professionals Participating in the Study ( $\mathrm{N}=704)$

\begin{tabular}{|c|c|c|}
\hline Sociodemographic feature & $\mathbf{n}$ & $\%$ \\
\hline \multicolumn{3}{|l|}{ Gender } \\
\hline Female & 543 & 77.1 \\
\hline Male & 161 & 22.9 \\
\hline \multicolumn{3}{|l|}{ Marital Status } \\
\hline Single & 269 & 38.2 \\
\hline Married & 435 & 61.8 \\
\hline \multicolumn{3}{|l|}{ Education Status } \\
\hline High School & 61 & 8.7 \\
\hline Associate degree & 97 & 13.8 \\
\hline Bachelor Degree & 364 & 51.7 \\
\hline Postgraduate & 182 & 25.9 \\
\hline \multicolumn{3}{|l|}{ Profession } \\
\hline Physician & 105 & 14.9 \\
\hline Nurse/ Midwife & 342 & 48.6 \\
\hline $\begin{array}{l}\text { Social worker/ Psychologist/ Physiot- } \\
\text { herapist }\end{array}$ & 35 & 5.0 \\
\hline Health Technician & 75 & 10.7 \\
\hline DEO/DPCO & 49 & 7.0 \\
\hline Other healthcare professionals* & 32 & 4.5 \\
\hline $\begin{array}{l}\text { Staff providing support and manage- } \\
\text { ment services** }\end{array}$ & 66 & 9.4 \\
\hline \multicolumn{3}{|l|}{ Income Status } \\
\hline Income is less than expenses & 249 & 35.4 \\
\hline Income is equal to expenses & 348 & 49.4 \\
\hline Income is more than expenses & $\begin{array}{c}107 \\
\text { Mean } \pm S D\end{array}$ & $\begin{array}{c}15.2 \\
\text { Median } \\
\text { (min.-max.) }\end{array}$ \\
\hline Age (years) & $35.97 \pm 8.76$ & $35(18-65)$ \\
\hline $\begin{array}{l}\text { Duration of employment in the profes- } \\
\text { sion (years) }\end{array}$ & $12.93 \pm 9.19$ & $11(0-42)$ \\
\hline
\end{tabular}

DEO / DPCO: Data Entry Operator / Data Preparation and Control Operator

*Other healthcare professionals $=$ Other health licensees (except healthcare managers): Paramedic / Dietician / Child development specialist/ Dental clinical support staff / Biologist / Pharmacist / Dental prosthesis technician / Environmental health technician / Chemist / Laboratory staff

**Staff providing support and management services: IT / Office staff / Computer operator / Officer / Accounting / Architect / Engineer / Administrative staff / Worker / Technical staff / Cleaning staff / Security officer
$45.7 \%$ of the healthcare professionals participated in disability related events (conference, education etc.) and $73.3 \%$ of the participants stated that they would like to participate in an education or activity related to the disabled (Table 1).

Mean ATDP scale score of the healthcare professionals included in the analysis was determined as 64.95 \pm 13.94 (median, 65; minimum, 28; maximum, 103). Table 2 shows the ATDP scores of the research

Table 2. ATDP Scores of Healthcare Professionals Participating in the Study according to their Sociodemographic Characteristics and their Experience with Disability ( $\mathrm{N}=704)$

\begin{tabular}{|c|c|c|}
\hline Characteristics/Experience & $\mathrm{X} \pm \mathrm{SD}$ & $\begin{array}{l}t / p \\
F / p\end{array}$ \\
\hline \multicolumn{3}{|l|}{ Gender } \\
\hline Female & $65.55 \pm 13.74$ & $2.098 / 0.036^{*}$ \\
\hline Male & $62.93 \pm 14.43$ & \\
\hline \multicolumn{3}{|l|}{ Marital Status } \\
\hline Single & $66.38 \pm 14.10$ & \\
\hline Married & $64.07 \pm 13.77$ & $-2.139 / 0.033^{*}$ \\
\hline \multicolumn{3}{|l|}{ Education Status } \\
\hline High School & $58.85 \pm 13.77$ & \\
\hline Associate degree & $60.79 \pm 14.53$ & \\
\hline Bachelor Degree & $65.60 \pm 13.15$ & $10.144 /<0.001^{* *}$ \\
\hline Postgraduate & $67.91 \pm 14.19$ & \\
\hline \multicolumn{3}{|l|}{ Profession } \\
\hline Physician & $69.69 \pm 13.74$ & \\
\hline Nurse/ Midwife & $63.87 \pm 13.10$ & \\
\hline $\begin{array}{l}\text { Social worker/ Psychologist/ } \\
\text { Physiotherapist }\end{array}$ & $74.26 \pm 11.96$ & \\
\hline Health Technician & $63.81 \pm 13.54$ & $8.967 /<0.001^{* *}$ \\
\hline DEO / DPCO & $56.84 \pm 14.57$ & \\
\hline $\begin{array}{l}\text { Other healthcare } \\
\text { professionals }\end{array}$ & $69.00 \pm 15.07$ & \\
\hline $\begin{array}{l}\text { Staff providing support and } \\
\text { management services }\end{array}$ & $63.42 \pm 14.10$ & \\
\hline \multicolumn{3}{|l|}{ Income Status } \\
\hline Income is less than expenses & $62.73 \pm 14.50$ & \\
\hline Income is equal to expenses & $65.64 \pm 13.59$ & $6.043 / 0.003 * *$ \\
\hline Income is more than expenses & $67.88 \pm 13.02$ & \\
\hline \multicolumn{3}{|l|}{$\begin{array}{l}\text { The presence of a disabled } \\
\text { person in the family or close } \\
\text { environment }\end{array}$} \\
\hline Yes & $64.53 \pm 13.86$ & $0.788 / 0.431^{*}$ \\
\hline No & $65.36 \pm 14.02$ & \\
\hline \multicolumn{3}{|l|}{$\begin{array}{l}\text { Disability-related education etc. } \\
\text { event attendance status }\end{array}$} \\
\hline Yes & $65.49 \pm 13.23$ & $-0.950 / 0.342^{*}$ \\
\hline No & $64.49 \pm 14.51$ & \\
\hline \multicolumn{3}{|l|}{$\begin{array}{l}\text { Working experience in a unit } \\
\text { dealing with the disabled }\end{array}$} \\
\hline Yes & $65.63 \pm 14.48$ & $-0.729 / 0.466^{*}$ \\
\hline No & $64.73 \pm 13.76$ & \\
\hline \multicolumn{3}{|l|}{$\begin{array}{l}\text { Willingness to take part in a } \\
\text { training/event related to the } \\
\text { disabled }\end{array}$} \\
\hline Yes & $65.58 \pm 14.14$ & $-1.982 / 0.048^{*}$ \\
\hline No & $63.23 \pm 13.24$ & \\
\hline
\end{tabular}

ATDP: Attitude Toward Disabled Persons

*Independent sample t-test, **One-way ANOVA test (Post-hoc test:Bonferroni test) 
group according to their sociodemographic characteristics and experience with disability.

When the ATDP scale scores of the healthcare professionals participating in the study were evaluated, it was found to be significantly higher in women compared to men ( $p=0.036)$; and higher in singles than in married $(p=0.033)$.

ATDP scale scores varied according to the education level of the participants $(p<0.001)$. While there was no difference between the scores of bachelor degree graduates and postgraduates, and also between the scores of high school and associate degree graduates $(p=0.382$ and $p=1000)$, the scale scores of both bachelor degree graduates and postgraduates were higher than associate and high school graduates ( $p$ values: bachelor degree graduate-high school: $<0.002$; bachelor degree graduate-associate degree: 0.013; postgraduate-high school: <0.001; postgraduate-associate degree: $<0.001$ ).

Mean ATDP scale scores were significantly different according to the income level of the participants $(p=0.003)$. While there was no significant difference between those whose income was higher than their expenses or equal to their expenses $(p=0.432)$. The scores of those whose income was equal to their expenses or higher than their expenses received significantly higher scores than those whose income was less than their expenses ( $p$ values: 0.034 and 0.004 , respectively).

ATDP scale scores were different according to professional groups $(p<0.001)$. While the professional group with the highest scale score average was the "social worker/ psychologist/ physiotherapist" group, the profession group" DEO/DPCO: Data Entry Operator/Data Preparation and Control Operator" had the lowest scale score average (Table 2). When the difference between the groups was evaluated in detail, it was seen that the scale score of the "social worker/psychologist/physiotherapist" group was not statistically different from the "physician" group and "other healthcare workers" group ( $p=1.000)$, but was significantly higher than all other groups ( $p$ values $<0.05$ ). While the scale scores of the "nurse/midwife" profession group were significantly lower than the "social worker/psychologist/physiotherapist" group and the "physician" group $(p<0.001$ and $p=0.003$ ), they had significantly higher scores than the "DEO/DPCO: Data Entry Operator/Data Preparation and Control Operator" profession group $(p=0.014)$. While the scale scores of the "DEO/DPCO: Data Entry Operator/Data Preparation and Control Operator" profession group were not different from the "health technician" group and the "support and management staff" group ( $p=0.105$ and $p=0.206)$, they had significantly lower scores than other professional groups $(p<0.05)$.

No significant relationship was found between the age of healthcare professionals or the duration of their employment and ATDP scores in correlation analysis ( $r=-0.014 ; p=0.703$ and $r=-0.038 ; p=0.319$ ).

ATDP scale scores did not change according to the experiences of the healthcare professionals participating in the study about disability (Table 2). However, the mean scale scores of those who stated that they wanted to participate in a training or activity related to disability were significantly higher than those who did not $(p=0.048)$.

\section{DISCUSSION}

All healthcare professionals are expected to provide the highest level of healthcare service to disabled individuals and equal services to each individual without any discrimination. There are studies in the literature reporting that the sociodemographic characteristics of healthcare professionals have an impact on their attitudes towards disabled people ${ }^{(14-16)}$. In terms of this point of view, our research found that the mean ATDP score, used to determine the participants' attitudes towards disabled individuals, was $64.95 \pm 13.94$. This result shows that healthcare professionals have positive attitudes towards people with disabilities. Kılıç and Çıtıl's study with physicians and nurses in performed in 2019 revealed a moderate positive attitude, similar to our study ${ }^{(17)}$. Sarı et al. ${ }^{(16)}$ reported that nursing students had positive attitudes towards disabled people. On the other hand, in a study conducted with health vocational high school students in Niğde/Turkey, it was determined that nursing students did not have positive attitudes towards disabled individuals ${ }^{(18)}$. Similarly, in the study in which detailed interviews were used 
to investigate the attitude towards the disabled in Nepal, the attitudes of the health professional towards the disabled were examined, and it was found that the majority of the participants had negative attitudes towards disabled people; and their knowledge and skills were insufficient in the provision of health services for disabled individuals (19). Kim et al.'s ${ }^{(20)}$ study conducted in Korea stated that health professionals had negative attitudes towards disabled individuals.

The ATDP scores of the female healthcare professionals were higher compared to male participants (Table 2). It has been reported in several studies in the literature that female healthcare professionals have more positive attitudes towards disabled individuals than males ${ }^{(14,15,21)}$.

However among health vocational high school students in Niğde/Turkey, it was found that the total score of the scale was higher in males than females, that is, male students had a more favourable attitude towards disabled people ${ }^{(18)}$. But another study conducted by Sarı et al. ${ }^{(16)}$ with nursing students revealed that the average score of female students was significantly higher than that of males. This shows that male nursing students have more negative attitudes towards disabled individuals than female nursing students. On the other hand, in the study of Kılıç and Çıtıll ${ }^{(17)}$ performed in 2019, no significant difference was found between the participants' attitudes towards disabled individuals according to their gender. The fact that women have more favourable attitudes can be explained by their gender characteristics such as being more caring, compassionate, affectionate, emotional, and sensitive to the feelings and thoughts of others.

In our study, according to the marital status of the participants, the attitude of single individuals towards disabled individuals was found to be more favourable than married individuals (Table 2). Kılıç and Çıtıl (17) reported differently from our study, and found the marital status of the participants did not have a significant effect on the attitudes of the participants towards disabled individuals.

A statistically significant difference was found in our study between the ATDP scores according to the education level. The average scores increased as the education level increased, but there was no difference between the scores of undergraduate and graduate degree participants, and also between the scores of high school and associate degree graduates. The scale scores of both undergraduate and graduate degree participants were found to be higher than associate and high school graduates, and they maintained more favourable attitudes towards disabled individuals (Table 2). Kılıç and Çıtıl (17), reported that there was an inverse relationship between the education level of the participants and their attitudes towards disabled individuals. Similarly, in a study conducted in Manisa/Turkey, it was observed that as the education level increased, the positive attitude towards disabled individuals decreased; and it was determined that the positive attitudes of individuals with elementary education and below were statistically significantly stronger than those with higher education levels ${ }^{(22)}$. In a study conducted for employers in Bolu/Turkey, no significant difference was found between the education level and the attitude towards disabled people ${ }^{(23)}$.

In our study, it was found that the attitude towards the disabled was significantly more favourable in those whose income was equal or higher than their expenses (Table 2). However in a study conducted with nursing students, it was reported that the economic status of nurses did not have a significant effect on their attitudes towards disabled people ${ }^{(24)}$. On the other hand, in a study conducted in Ireland, it was found that individuals with better economic status had increased awareness about disabled people ${ }^{(25)}$.

We did not find any statistically significant difference between the presence of a disabled member in the family of the participants and their ATDP scores (Table 2). In some studies in the literature, similar to our study findings, no significant relationship was found between the attitudes towards disabled individuals among the relatives of the participants according to their status of being a disabled individual $(16,26)$. Likewise, in a study conducted with students of a faculty of medicine, it was found that the presence of a disabled person in their family or environment did not have an effect on students' attitudes towards disabled people ${ }^{(25)}$. On the other hand, there are some studies 
showing that having a previous interaction with disabled people positively affects attitudes towards persons with disabilities ${ }^{(12,19)}$.

There are studies in the literature showing that having any previous education on disability has positive effects on attitudes towards persons with disabilities $(14,24,28)$. In an intervention study conducted with nursing students at two different universities in Konya/ Turkey, it was determined that the group which received training on empathy activities and information for the disabled was much more positively affected than the control group ${ }^{(29)}$. Through educational programs about disability, future professionals will be able to provide more effective health care to people with disabilities and have the chance to provide health care services on important issues. It is reported that this situation will provide an important opportunity for physicians to gain the skills that enable them to provide patient-centered care to disabled individuals ${ }^{(30)}$. In a USA study with participating nursing students, it was found that education significantly affects the attitude maintained towards disabled people ${ }^{(31)}$. Ilkhani et. al. ${ }^{(32)}$ studied the literature review of the nursing curriculum related to the care of disabled children. Among 78 studies examined, it was determined that only six research articles included all the keywords "education, disability and curriculum" and that the best approach in caring for children with disabilities was to increase the quality of education among healthcare professionals. Themes derived from these studies may be that various activities on disability before and after graduation will increase the awareness level of health personnel and have positive effects on their attitudes towards disabled people.

In the study conducted with nurses in Istanbul, Ayyıldız et al. ${ }^{(33)}$ reported that more than half of the participants did not receive a training for the disabled within the scope of the curriculum during their education. In our study, the ATDP scale scores of those who stated that they wanted to participate in an education/training or activity related to disability were significantly higher than those who did not (Table 2). There are studies revealing that the status of receiving education for the disabled significantly affects the attitudes towards people affected by disability significantly ${ }^{(13,17)}$.
The strengths of our study can be stated as follows. Unlike similar studies in the literature, we did not only include physicians and nurses, in our survey, but also almost all professional groups providing health services were enrolled. Besides all of the participants answered the questions without worrying about being tagged because the survey was conducted online and anonymously. On the other hand, the fact that the institution types of the employees participating in the study were not inquired, the people who were interested/sensitive to the subject might have been more inclined to answer the questionnaire items; and the research group did not represent the healthcare professionals in the province as a whole can be counted among the limitations of the study.

\section{CONCLUSION and RECOMMENDATIONS}

Although disabled individuals encounter many problems in their environment, perhaps the most important of these problems is about receiving health services. Compared to the general population, disabled individuals encounter health problems more often, and require health service more frequently ${ }^{(4)}$.

In our study, it was determined that the mean ATDP score used to determine the attitudes of healthcare professionals towards disabled individuals was 64.95 \pm 13.94 . It has been observed that healthcare professionals have a positive attitude towards disabled individuals. In order to further develop the positive attitudes of healthcare professionals towards persons with disabilities;

- The education of healthcare professionals should include courses that increase attitude and awareness towards disabled people.

- The perception of disability as "disorder", "abnormality" or "impaired" should be supported by organizing in-service training programs for the disabled at regular intervals in health institutions.

- Disability units should be established in health institutions. Disability professionals should work in these units. Necessary opportunities should be provided for these professionals to develop in the field of disability. 


\section{Acknowledgements}

We would like to thank Prof. Dr. Kemal Memişoğlu (Director of Istanbul Health Directorate - project owner) and project coordinator team for facilitating the research process.

Ethics Committee Approval: The study was approved by the Ethical Committee of Health Sciences University Gaziosmanpaşa Taksim Training and Research Hospital (2019/163).

Conflict of Interest: The authors state that they have no conflict of interest.

Funding: "Be Happy in Life" Erasmus+ KA2 EU Project (Project Number: 2018-1-TR01-KA204058392) is funded by the Turkish National Agency and carried out in coordination with the Provincial Health Directorate of Istanbul. The project is funded by the Erasmus+ Programme of the European Union. However, European Commission and Turkish National Agency cannot be held responsible for any potential use of the information contained therein. For this research study conducted within the scope of the project, no payment was made from the project budget, and the project team conducted the research in order to identify local problems.

Informed Consent: At this research, it was not studied with the patient.

\section{RERERENCES}

1. World disability report executive summary. www.who. int/disabilities/world_report/2011/en.April 7, 2019.

2. Arıkan Ç. Sosyal Model çerçevesinde engelliliğe yaklaşım. Ufkun Ötesi Bilim Dergisi 2002;2(1):12-21.

3. Kara B. Türkiye'de engelli bireylerin yasal hakları ve uygulamadaki yeri. The Journal of Academic Social Science Studies 2016;48:249-60. [CrossRef]

4. Inan S, Ceyhun Peker G, Tekiner S, Ak F, Dağlı Z. Engellilik, türkiye'de engellilerin durumu ve sağlık hizmet sunumuna bakış. TAF Prev. Med. Bull 2013;12(6):723-8.

5. Türkiye Cumhuriyeti Başbakanlık Özürlüler İdaresi, Devlet İstatistik Enstitüsü Başkanlığı, Türkiye Özürlüler Araştırması. Ankara: Devlet İstatistik Enstitüsü Matbaası; 2009. s. 5-30.

6. Kolat S. Avrupa Birliği sosyal politikası çerçevesinde özürlülere yönelik ayrımcılıkla mücadele ve Türkiye'deki yansımalar, T.C. BaşbakanlıkÖzürlüler İdaresi Başkanlığı. Ankara; 2010.s. 45-48.

7. Özden AS, Tekindal M. Engellilik ile Ilgili Modeller. EngellilikAlanında Sosyal Hizmet Kuram ve Uygulamaları (1. Baskı). Ankara: Nobel Yayınları; 2020. s.33-42.8. Kördeve MK. Engelli Bireylerin Sağlık Hizmeti Alımında Karşılaştıkları Problemler. Usaysad Dergisi 2017;3(2):188-98
9. Yuker HE, Block JR, Campbell WJ. A scale to measure attitudes toward disabled persons. New York: Ina Mend Institute at Human Resources Center; 1970. p.18-42.

10. Büyüköztürk Ş. Anket geliştirme. Türk Eğitim Bilimleri Dergisi 2005;3(2):133-51.

11. Boynton, $\mathrm{H}$ ve Greenhalgh, T. Hands-on guide to questionnaire research: Selecting, designing, and developing your questionnaire. BMJ (online) 2004;328(7451):1312-5.

12. Özyürek M. Tutumlar ve Yetersizlikten Etkilenmişlere Yönelik Tutumların Değiştirilmesi (5. Baskı). Ankara: Kök Yayınları; 2013. s.11-33

13. Alptekin S, Batık VM. Özel eğitim bölümü öğrencilerinin yetersizlikten etkilenmiş kişilere yönelik tutumlarına özel eğitim dersinin etkisi. Uluslararası Eğitim Araştırmaları Dergisi 2013;4:18-34.

14. Tervo RC, Palmer G, Redinius P. Health professional student attitudes towards people with disability. Clin Rehabil 2004;18(8):908-15. [CrossRef]

15. Au KW, Man DWK. Attitudes toward people with disabilities: A comparison between health care professionals and students. Int J Rehabil Res 2006;29(2):15560. [CrossRef]

16. Sarı YH, Bektaş M, Altıparmak S. Hemşirelik öğrencilerinin engellilere yönelik tutumlarının belirlenmesi. Yeni Tıp Dergisi 2010;27:80-3.

17. Kılıç E, Çıtıl R. Attitudes of Physicians and Nurses Towards the Disabled and Awareness of Applications for the Disabled in a University Hospital. Turkish Journal of Family Medicine and Primary Care 2019;13(2):129-41. [CrossRef]

18. Hisar KM, Samancı Tekin Ç. Sağlık meslek lisesi öğrencilerinin engellilere karşı tutumlarının belirlenmesi. 16. Ulusal Halk Sağlığı Kongresi, Antalya, 27-31 Ekim 2013. p 339.

19. Devkota HR, Murray E, Kett M, Groce N. Healthcare provider's attitude towards disability and experience of women with disabilities in the use of maternal healthcare service in rural Nepal. Reproductive Health 2017;14(1):79. [CrossRef]

20. Kim K, Park YH, Lee BS, Kim JY. Comparison of the attitudes toward and contact with disabled person among health care professionals, lay persons, and disabled persons. Korean J. Rehabil. Nurs 2010;13(1):13-22.

21. Thompson TL, Emrich K, Moore G. The effect of curriculum on the attitudes of nursing students toward disability. Rehabil Nurs 2003;28(1):27-30. [CrossRef]

22. Altıparmak S, Sarı HY. Manisa ilinde engelli bireylere karşı toplumsal tutum. Anadolu Psikiyatri Dergisi 2012;13(2):110-6.

23. Eratay E, Çetin EM. Bolu İlindeki İşverenlerin Engelli Çalışanlara Yönelik Tutumları. Kastamonu Eğitim Dergisi 2013;21:1681-94.

24. Uysal A, Albayrak B, Koçulu B, Kan F, Aydın T. Attitudes of nursing students toward people with disabilities. Nurse EducationToday 2014;34(5):878-84. [CrossRef]

25. http://nda.ie/Publications/Attitudes/Public-Attitudesto-Disability-in-Ireland-Surveys/Public-Attitudes-toDisabilty-Survey-PDF.pdf.April 8, 2019.

26. Şahin $H$, Bekir $H$. Üniversite öğrencilerinin engellilere yönelik tutumlarının belirlenmesi. Türkiye Sosyal Araştırmalar Dergisi 2016;20(3):767-79.

27. Gökçe A, Güneş G, Seyitoğlu ÇD. İnönü Üniversitesi Tıp 
Fakültesi öğrencilerinin engellilere yönelik tutum ve davranışları. Medicine Science 2016;5(2):351-62. [CrossRef]

28. Seccombe JA. Attitudes towards disability in an undergraduate nursing curriculum: A literature review. Nurse Educ Today 2007;27(5):459-65. [CrossRef]

29. Geçkil E, Kaleci E, Cingil D, Hisar F. The effect of disability empathy activity on the attitude of nursing students towards disabled people: a pilot study. Contemp Nurse 2017;53(1):82-93. [CrossRef]

30. Lezzoni LI, Long-Bellil LM. Training physicians about caring for persons with disabilities: "Nothing about us without us!". Disabil Health J 2012;5(3):136-9.

31. Cervasio K, Fatata-Hall K. The Attitudes of Nursing Students Toward Children With Disabilities: An Experimental Design. Int J Phys. Med. Rehabil 2013;1:140-55.

32. Ilkhani M, Glasper A, Jarrett N. Nursing curricula relating to care for disabled children: literature review. Int Nurs Rev 2016;63(1):78-83. [CrossRef]

33. Ayyıldız N, Ulupınar S. Health education activities of the nurses working in the primary care health services towards disabled persons. Journal of Health Science and Profession 2019;6(1):51-61. 